\title{
ASSESSMENT OF ABUSIVE SUPERVISION - BOSS METHODOLOGY
}

\author{
Zuzana BIRKNEROVÁ (DD) ${ }^{1}$, Lucia ZBIHLEJOVÁ (iD ${ }^{2}$, Milan DROPPA (D) 3 \\ ${ }^{1}$ Department of Managerial Psychology, Faculty of Management, \\ University of Prešov, Prešov, Slovakia \\ ${ }^{2}$ Department of Intercultural Communication, Faculty of Management, \\ University of Prešov, Prešov, Slovakia \\ ${ }^{3}$ Štefan Nahálka Institute in Poprad, Faculty of Education, \\ Catholic University in Ružomberok, Ružomberok, Slovakia
}

Received 29 May 2019; accepted 27 April 2020

\begin{abstract}
Concerning the issue of conceptualization and operationalization of abusive supervision, contemporary studies including the one presented below discuss several issues. The presented paper is aimed at the downward (vertical) form of workplace bullying, described in literature as abusive supervision or bossing, and the form of its assessment within the work environment. Furthermore, a new original methodology designed to measure bossing psychometrically, is proposed and labeled as BOSS. On the basis of the research results, which involved participation of 525 respondents (non-managerial workers; $40 \%$ men and 60\% women), two factors of the BOSS methodology were extracted and labeled as: Communication-Aimed Bossing and Psyche-Aimed Bossing. Bossing is typically manifested within two distinct areas represented by these extracted factors. The full version of the BOSS methodology is also presented in the paper.
\end{abstract}

Keywords: bullying, mobbing, bossing, abusive supervision, BOSS methodology, manager.

JEL Classification: C18, J71.

\section{Introduction}

Workplace bullying is a phenomenon as old as work itself but it has come to the forefront in the early 1990s as a major cause of labor productivity reductions, tension increase and work absence caused by mental disorders naturally generated by it (Hirigoyen, 2000). The purpose of this research is to study this phenomenon from the viewpoint of its verticality, which is bullying triggered particularly by a supervisor and aimed at a subordinate known as abusive supervision (e.g. Camps et al., 2016; Wilson \& Nagy, 2017) or, as will be presented below,

*Corresponding author. E-mail: lucia.zbihlejova@unipo.sk

Copyright (c) 2020 The Author(s). Published by Vilnius Gediminas Technical University

This is an Open Access article distributed under the terms of the Creative Commons Attribution License (http://creativecommons. org/licenses/by/4.0/), which permits unrestricted use, distribution, and reproduction in any medium, provided the original author and source are credited. 
bossing (Zikic et al., 2013), by means of proposing a methodology designed to measure bossing manifestations in the workplace.

Although bullying can affect anyone anywhere, there are industries where it can occur more often, where it has the most suitable conditions to develop. In every field, one can also find a boss who resorts to bullying subordinates. For instance, Smith et al. (2016), Karabacak Aşır and Akın (2014) aimed their studies at school bullying and mobbing among the primary school teachers. There are also other specific fields, where workplace bullying has its unfortunate place, and which are subject to ongoing studies. Yildiz (2015), for example, measured bullying within the professional football environment to test the relationship between bullying and burnout and its effects on these players. Tuzunkan (2018) has recently focused on mobbing manifestations in tourism enterprises, and Zacharová and Bartošovič (2016) have been studying the issues of bullying in health care facilities, as experienced by nurses.

This particular research is crucial in the education of future managers with an emphasis on drawing attention to undesirable forms of behavior and their consequences, as bossing is a very specific mode of bullying in the workplace, mobbing and persecution by the boss, where the psychological coercion is initiated by the supervisor (Novák, 2004). There is a very thin line between the normal albeit harsh behavior of the boss and bullying (Bednar, 2016). The manifestations of this behavior have a dangerous form, as the superior has relatively considerable powers that can easily be abused. The managing worker usually overloads the subordinates, assigns tasks that are not manageable, disproportionately evaluates the work done, creates psychological pressure and so on (Borská, 2005). According to Olšovská (2013), in the case of bossing, it is a conscious reduction of dignity and intimidation of an employee by the superior, resulting in mental, moral, physical or social harm. The aggressor's goal is to disrupt the worker's working environment, mostly to emphasize their hierarchical position in the company, to retain power, or from various personal interests towards the employee (Frankovský et al., 2019b).

As for the operationalization of horizontal bullying, i.e. mobbing, the previously conducted study by Zukauskas and Vveinhardt (2011) enabled the development of an instrument to measure mobbing as a form of discrimination in employees relations in order to improve organizational climate. Zukauskas et al. (2015) also studied the occurrence and prevalence of different mobbing actions particularly in the context of Lithuanian organizations. Their research revealed that the most prominent mobbing strategies include insulting communication attacks with the purpose of ruining the professional reputation and social relations of the victims (Jenčo et al., 2018).

This study was designed to shift the focus from horizontal mobbing to the vertical one - bossing. The presented report, therefore, focuses on bossing and the methods of its assessment in the work environment. Furthermore, a new bossing-aimed methodology representing a psychometric measurement tool is proposed and labeled as BOSS. The main aim of the presented research is to verify BOSS by means of the Factor Analysis (Principal Component Analysis with Varimax Rotation). For the purposes of validation of the original BOSS methodology, the NAQ by Einarsen, Raknes, Matthiesen, and Hellesøy (1994, as specified and referred to in Hoel et al., 1999) was used. 
The paper is divided into four main sections. The first contains a theoretical background to the issues of mobbing and bossing, which is followed by the description of the methods used to assess bullying in the workplace. The next section is dedicated to the proposal and verification of the original BOSS methodology, which is followed by the concluding remarks to the studied issue.

\section{Theoretical framework}

\subsection{Workplace bullying: Mobbing and abusive supervision - bossing}

Safina and Podgornaya (2014) define bullying is a moral and often possibly physical persecution at the workplace or, in other words, harassment, pressure, or mental terror. The authors further point out that bullying occurs when an individual is oppressed by a group of people or by another individual. When the initiator of aggression is a senior executive, this kind of bullying is called bossing. Abusive supervision, i.e. bossing is specified by a Swedish sociologist Leymann (1990) in terms of several categories, such as the impossibility of expressing oneself, entrusting other (interruption, criticism, threatening), attacking social relations (ignoring, excluding), reproaching, threatening seriousness and respect (gossiping, defamation), criticizing work and personal life (meaningless and unfulfilled tasks), and threatening health (sexual harassment). The author points out the phases of bossing: first of all, it is a matter of malevolence or Schadenfreude, later it becomes a regular psychological pressure with deliberate intent, then turns into targeted attacks and work overloading, and ends with the decomposition of the personality of the affected worker and the subsequent work dismissal. According to Leymann (1990), Hoel et al. (1999) and other authors, mobbing and bossing occur when at least once a week for at least six months the affected person is assaulted by one or more people.

Kolář (2005) develops the idea of a possible three-dimensional view of bullying. The author describes bullying as a sick behavior, an addiction, and as a disorder of relationships within a group. Bullying is a demonstration of the superiority of one person over another, which can happen for various reasons (Droppa et al., 2018). Novák and Capponi (1996) report that by means of bullying, the aggressor attempts to gain various benefits, dominance, and satisfaction.

As several authors (e.g. Yaman, 2009; Senol et al., 2015) point out, mobbing, as a horizontal form of workplace bullying, is a phenomenon found between two or more people working on the same position within the hierarchy of an organization from the lowest working positions to the top management (i.e. just as a production worker can mob another production worker, a top manager can mob another top manager). Contrarily, bossing is a type of abuse which is directed from a higher-level position to a lower-level position within the organizational hierarchy (i.e. supervisor/manager can use bossing on the subordinates, or a top manager can use it to abuse a lower-level type of a manager).

Kariková and Šimegová (2005), Nekoranec and Kmošena (2015) support these claims by defining mobbing as using conspirations and intrigues in a work team to abuse co-workers systematically and relentlessly, while bossing occurs when a superordinate worker (boss, manager) terrorizes one or more employees (subordinates) psychologically. 
According to Arnejčič (2016), bossing is a form of what he calls "vertical wall" mobbing. It takes place when a person tries to denigrate his or her subordinate. Oberhofer (2018) also uses the term staffing (upward bullying by subordinates) as opposed to bossing (downward bullying by superordinates), accentuating that both these terms are typical primarily in German-speaking regions of Europe. Zikic, Paunkovic, and Cvetkovic (2013) agree with this theory, stating that vertical form of mobbing (abusive supervision, bossing) occurs when a supervisor mobs a subordinate.

The research study conducted by Russo and Popović (2016) presents bossing as a phenomenon which occurs frequently in the workplace, where one or more supervisors apply ongoing aggression on a selected subordinate or group of subordinates.

Hamilton, Ogbuigwe and Gabriel (2017, p. 739) also present the term toxic bossing, which they describe as forms of abusive behavior "directed toward subordinates or groups within the workplace which are intentional and aimed at manipulating them with explicit and implied threats, and also adopted as means of undermining workers and creating barriers within the organization". For instance, Emelander (2011) uses the term "boss syndrome", which occurs among bosses who, as managers or as leaders, do not know how to handle the most important resource of the company, i.e. its people. By means of their approach, such bosses thus threaten the overall performance of the working teams, as well as the mental well-being of the individuals involved (Antonyová et al., 2018).

Occupational medicine uses the terms mobbing and bossing only when a person is assaulted systematically and for a long time. It is most prominent where bullying and intrigues become routines, with individual cases being not necessarily noticeable or serious (Huberová, 1995). The concept of mobbing in the workplace refers to situations in which the employee is constantly exposed to negative and aggressive behavior at work, particularly of a psychological nature (Leymann, 1996) with the effect of humiliation, intimidation or punishment of the object of violence. Instead of acting discreetly, mobbing represents developing and often gradual hostile relationships in the workplace with repetition (frequency), duration, and includes various forms of behavior (Einarsen et al., 2009).

The difference between mobbing and bossing, albeit being similar terms, is in the actors of mental bullying. The dark side of it is that when the manager is the bully, the consequences for the victim can be deeply serious. Huberová (1995) believes that employees often encounter situations which threaten them more than any other. Besides distorting their personal happiness and endangering social contacts, the threat extends over their career, economic existence, and professional identity. Novice workers, unexperienced both socially and workwise, are an especially threatened group (Birknerová et al., 2010). In addition to mobbing, supervisors or managers are often performers of mental assault they inflict upon their subordinates, and this is called abusive supervision or bossing.

Jenčo et al. (2018) define bossing as dangerous behavior that can influence the long-term cooperation of the working teams as well as the overall performance of an organization. The authors claim that bossing significantly lowers the employees's focus on meeting the goals of their organization, which is the natural consequence of the reduction of their work quality. Zhao (2018, p. 154) supports this by claiming that bossing or "abusive supervision can not only directly reduce the performance of subordinates, but also can have a negative impact on 
performance by reducing the identity of subordinates to leadership". Bossing evidently causes decrease in the performance of employees and therefore performance of an organization as a whole, particularly in terms of its sustainability. However, there are studies which have found the opposite. Lu (2013) argues that bossing may inspire job passion among employess and thus improve the overall performance of an organization. In this context it is therefore crucial to distinguish between what is bossing or abusive supervision (performance decrease) and what is requiring consistent performance of duties (performance increase). Another crucial point to be accentuated here is that bossing is not aimed primarily at the performance increase (decrease); it a form of satisfying one's psyche by means of bullying another person, i.e. creating the feeling of power, or it is a method used to get rid of an undesired employee (more in subchapter 1.3).

Overall, bullying in the workplace involves systematic, hostile and unethical communication and behavior of one or more people. The person to whom it is directed is pushed into a dead-end and defensive position and is maintained in it by continuing activities, which are usually very frequent and long-lasting (Leymann, 1990). This is not about one-off conflicts or misunderstandings, but about systematic intrigues, bullying, bad behavior and conduct towards others (Zapf \& Leymann, 1996). It is initiated and managed by colleagues, superiors or subordinates in order to harm someone with active and sustained pressure for a long time. The primary characteristic of mobbing as well as bossing is that they are long-term and systematic (Birknerová et al., 2010).

\subsection{Bossing}

In Slovakia, mobbing and bossing are relatively new concepts for bullying in organizations (Huberová, 1995). The consequence of the growing aggression in organizations in an effort to achieve as little effort as possible, i.e. the pressure on performance, is a fertile ground for this phenomenon. Abusive supervision (furthemore only as bossing) is basically a label for mobbing, the initiator of which is the leading worker (the boss) - thus it is the mobbing from above (Oberhofer, 2018). The author of this term is a Norwegian Kile (Beňo, 2003), who used this label to describe the systematic bullying by the executives. Assuming that the leader's duty is to create a favorable and comfortable work environment for their subordinate employees, it is necessary to say that bossing must be assessed as a more dangerous form than mobbing itself is (Hamilton et al., 2017).

A leader has other motives for bullying and uses other strategies than a co-worker. Among their basic motives is jealousy of a skilled worker and fear of losing their position, creating pressure on the subordinate worker to enforce their obedience, efforts to expel this person from the working team, or from the workplace as such (Olšovská, 2013). Anger at the organization is also notable, as well as hatred of the superiors, and negative personal qualities of the leader, which get an opportunity to manifest themselves at the moment when the individual acquires power or influence (Camps et al., 2016; Wilson \& Nagy, 2017). The basic strategies of bossing thus include assignment of Sisyphean tasks, totally nonsensical, deliberate assignment of inappropriate tasks that are far below the skill level of the affected worker, or, on the contrary, tasks which are too demanding, unmanageable (Frankovský et al., 2019a). 
Continuous control exceeding the workplace standard is one of the most widespread mobbing strategies of the superiors. It is very simple and inexpensive to perform, and the leader can justify it as fulfilling the duties arising from their function. Another method is the occupational isolation consisting in the fact that the worker is not invited to consultations, is not informed of important decisions, and is told that he or she is not counted on (Borská, 2005).

\subsection{Motives and objectives of bossing}

According to the research available in the literature (e.g. Davenport et al., 1999; Olšovská, 2013), there are several basic motives connected to mobbing and bossing in the workplace:

- endangering the social status of the bosser,

- endangering work or function of the bosser,

- endangering the freedom of action and decision-making of the bosser,

- the need to feel safe and be recognized,

- an effort to force an individual to adapt to standards,

- mutual antipathy, resenting the individual,

- sadistic motives, bossing for pleasure and fighting off boredom,

- prejudice and discrimination for various reasons.

However, the trigger momentum for the emergence of bossing may also be a common conflict or difference of the victim (Howladar et al., 2018). Bossing usually occurs in specific situations, particularly when a change in business management occurs, or when there is bad leadership in an organization, or a heavy workload. The purpose of bossing activities is then to prevent victims from interpersonal communication, minimize co-operation with the victim, block their social ties, harm their social respect, and shut off the victim from the work team or job (Hafidz, 2012). The tyranny begins in a painless way and spreads blatantly. Initially, the victims do not want to get insulted or angry at nothing, and they take various disagreements lightly. However, the number of attacks increases and the victim starts suffering from long-term hostility and degrading treatment (Bennett, 2000). Bossing is a long-term systematic pressure and this behavior no longer refers to a specific activity of an employee, but it is a constant pressure from the superior regardless of the activity the employee performs or what their behavior is at the particular time at the workplace (Russo \& Popović, 2016).

Several authors (e.g. Beňo, 2003; Kratz, 2005) agree that the goal pursued by mobbing or bossing is to force the victim to leave their position. The mobber/bosser tries to invent new and more aggressive weapons, which would destroy the victim systematically. The victim becomes uncertain, discontented, and restless, thinks about the causes of these attacks, stops doing good work, starts making mistakes, becomes the topic of spreading gossip not only about their private life but also criticizing their professional skills (Birknerová et al., 2010). The victim becomes even more nervous, psychosomatic problems start to appear, so they are more likely to be incapacitated, which will become noticeable to their superiors (Leymann, 1990). A vicious circle from which there is no escape begins to close. This means that the victim has been more or less brutally compelled to leave alone, whether by quitting the job or, in more cases, leaving by the so-called "termination by agreement". Another reason for the occurrence of bossing can be the strategy of a company that decides to dismiss its employee without having an objective 
reason (Emelander, 2011). Bossing is, therefore, a way to get rid of the employee without having to pay compensation.

\subsection{Causes of bossing}

Svobodová (2007) reports that there are many causes of workplace bossing. The main role is, of course, played by the personality of the bosser. Whether the bosser is provoked by the lack of sympathy, money, envy, fear of possible competition, or seeks satisfaction connected to the feeling of power, the result of their behavior is the disrupted social climate in the workplace. As mentioned above, Swedish psychologists (according to Davenport et al., 1999) offer, based on empirical research, four basic motives which lead a person to mob:

- The aggressor's social status is at risk.

- The work or the function of the aggressor is at risk.

- There is a threat to the aggressor's freedom of action and decision-making.

- The aggressor wants to feel safe and wants to be respected.

The reasons are various and often related. First of all, bossing can be caused by a low moral level or bad human qualities such as envy, antipathy, jealousy, and rivalry. The employee is often excluded from decision-making processes. The trigger mechanism of bossing is always a conflict that has not been properly settled or ended in some way (Oberhofer, 2018). It can thus lead to various bullying activities. Bossing can also be an expression of social tension that drifts to another person (Huberová, 1995). The victim of bossing can serve as a substitute object of aggression that is directed against someone else.

Wrong or inappropriate management style can also lead to bossing and many professionals, therefore, consider psychological terror to be the main problem of management (Borská, 2005). Competitive pressure and fear of losing the position can also be a major bossing factor. Their result is an unpleasant working climate and a ruthless job struggle (Birknerová \& Frankovský, 2017). For a boss, it is nothing simpler than to unleash their anger on others to relieve internal pressure and secure their own professional survival at their expense.

It is possible to assume that bossing manifestations will be more frequent in the companies or organizations with a low(er) level of corporate culture (e.g. Wu et al., 2018; Bellizzi, 2006), directive leadership styles (e.g. Tepper, 2000), and where the management is not based on the accepted norms of the system of quality. In terms of professions sensitive to bossing manifestations, there are those in which the position status is strictly defined (e.g. doctor and nurse). Thus, apparently, bossing manifestations can occur both at the entity as well as the individual level. In this context, entities with a defined management structure are more dominant (e.g. hospitals - one hospital can have a management structure which enables bossing manifestations, another one may be structured in a way that does not enable such manifestations). In connection to this, more attention could also be paid to the downward versus upward bullying (bossing vs. staffing), which may be directly manifested or hidden and seemingly non-existent.

Most workers feel a poor working environment is a stress factor number one and they suffer for it more than, for example, under the pressure of time or power (Borská, 2005).

Bossing is most frequently practiced by immature personalities, often with childish forms of aggressive behavior. The mental aggressor proceeds to intimidate the victim, who immedi- 
ately recovers and takes a defensive stance, sometimes already determined to attack (Russo \& Popović, 2016). Such a relationship gradually spreads to the psyche of both sides as an offensive and defensive reflex (in the aggressor, the view of the victim raises the anger; in the victim, the view of the aggressor provokes fear). The psycho-terror usually occurs only when the victim reacts negatively to the boss or another authority and refuses to succumb (Olšovská, 2013). They become a target of the attack actually due to their ability to withstand the authority despite the exaggerated pressure. The psycho-terror actor fundamentally underestimates the partner, allowing them to think that the victim will only get what they deserve.

The mobbing bosses usually proceed in their practice consistently, using the per partes method, where they always focus on an individual or, at most, a small group of employees. Bossing initiators are usually unbalanced people who are primarily driven by the fear of their own failure. In addition, these people suffer from reduced self-esteem, which, in this way, they seek to heighten (Brees et al., 2016). An offender is defined as an individual with an increased need to control and influence the environment. A bosser uses dictatorial and directional management, not allowing self-managing processes, which are a sign of a more advanced and mature team (Oberhofer, 2018). The bosser regularly assesses what has not been done in the past, and the worst is always the victim. Bossers worry about their social status, job, and function. They want to get rid of everyone they deem threatening. Their selfish interest is stronger than their conscience. Bossers consume a lot of their energy to invent new malpractices, not to create but to distort human relationships (Huberová, 1995). They are unable to train the team and lead it under difficult conditions. Executive or managing workers may become aggressors for the fear that their subordinates will "outgrow" them.

\subsection{Consequences of bossing}

The consequences of such mental abuse may vary depending on the degree of terror. Psychological pressure can be reflected in bad physical health, such as headaches and stomachs, insomnia, immunity reduction, anorexia, bulimia. Mental disorders are manifested as distraction, decreased work performance, restlessness, anxiety, nervousness, fear, depression, closure, night distress, psychiatric illnesses, or suicide attempts (Bennett, 2000; Hafidz, 2012; Howladar et al., 2018).

Everyone who practices a profession knows from their own experience that bad atmosphere and workplace conflicts have a significant impact on one's mood and often have more serious consequences than bad working conditions. Consequences for the society are expressed only in money, in lost labor and lost working time. Victims of bossing are often work incapacitated because workplace stress supports the emergence of other diseases and weakens the body. Such workers lose interest in their work. The vision of further terror in the workplace forces them to stay as far from it as possible (Einarsen et al., 2011).

Victims of bossing, as already mentioned, are often work incapacitated. The costs of longterm or repeated incapacity for work increase in the companies where bossing occurs. As a result of the poor working environment, there is also a higher staff turnover, a lack of motivation (Štefko et al., 2017), and, last but not least, an increase in production costs (Mikušová \& Horváthová, 2012). 
There are several consequences for the victim's professional situation; the victim does not receive job assignments or receives nonsensical ones. In many cases, this causes the victims' mental health problems and encourages them to lose their job (Huberová, 1995). A systematic fight against bossing should begin with the search for its cause. It is necessary to find out where and how the problem arose. The next stage should be to take steps to get the victim out of the problem. The victims should not wait for another person to solve the problem. It is also crucial to think about whether they themselves are not the main contributors to the initiation of bossing.

\section{Method}

Most research approaches to mobbing are aimed primarily at its consequences, outcomes, and what the victim experiences though it (Leymann, 1996), or on the description of individual undesired events in the workplace. One of the representatives of this approach is Professor Einarsen of the University of Bergen, Norway. With his colleagues, he designed the NAQ - Negative Acts Questionnaire. The methodology has undergone several modifications during its development.

In order to validate the original BOSS methodology, the NAQ by Einarsen, Raknes, Matthiesen, and Hellesøy (1994, in Hoel et al., 1999), which contains 29 items, was used. Studies carried out by means of this methodology (e.g. Hoel et al., 2001; Mikkelsen \& Einarsen, 2001) analyze the negative acts of behavior and the mobbing behavior, especially in the Scandinavian countries and the UK. These studies show that workplaces tend to be dominated by the manipulative behavior (work assignments, mocking; Tomková \& Lorincová, 2017) rather than the aggressive behavior (threats, shouting, etc.).

In this research, a methodology designed to measure workplace bossing was proposed. The BOSS methodology consists of 17 items depicting various ways of bossing in the workplace. The task for the respondents was to read each item carefully and assess it on a 5-point scale $(1=$ absolutely disagree, $2=$ rather disagree, $3=$ neither disagree nor agree, $4=$ rather agree, 5 = absolutely agree). Similarly to NAQ, this methodology represents a perfected modification of its pilot verification carried out by Frankovský, Birknerová and Droppa (2019a).

\section{Analysis and results}

In this research, 525 respondents, who were all non-managerial workers, were addressed. Of the total number, $210(40 \%)$ were men and $315(60 \%)$ were women, all older than 25 years, with the largest group (76.7\%) consisting of the employees aged between 31 and 50 years. $512(97.5 \%)$ of the respondents reported to have been university graduates. Participation of the respondents was voluntary and anonymous, respecting the General Data Protection Regulation (Regulation (EU) 2016/679 and Directive (EU) 2016/680). The data was collected using the Snowball sampling method.

The main objective of the research was verification of the methodology designed to measure bossing psychometrically. By means of Principal Component Analysis with Varimax Rotation, two bossing factors were extracted (Figure 1, Tables 1a and 1b). 


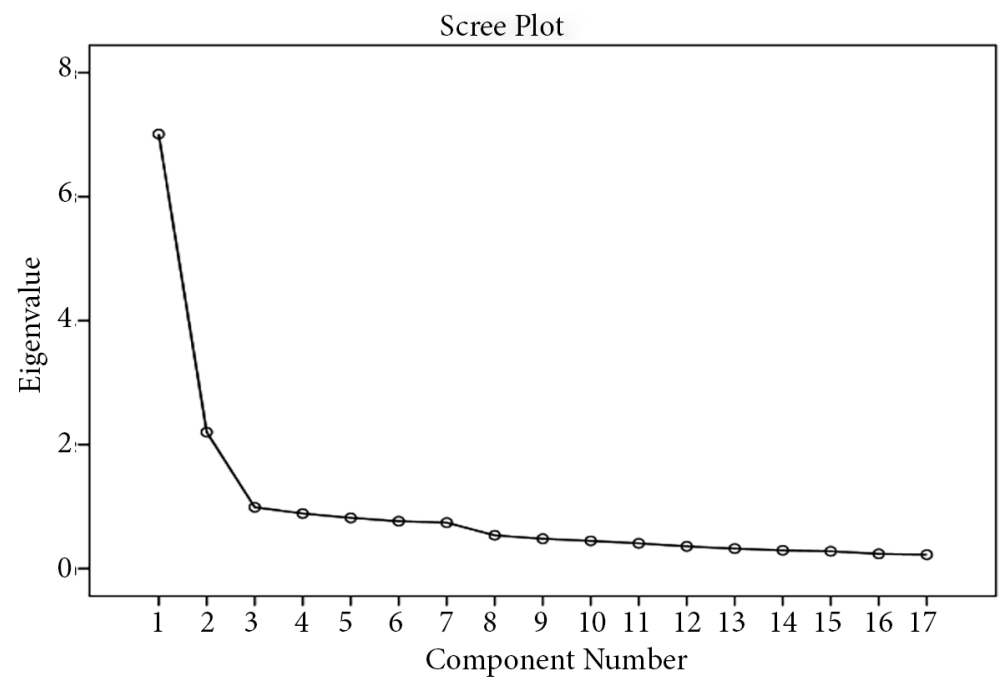

Figure 1. Extracted factor structure of the BOSS methodology

Table 1a. BOSS factor structure

\begin{tabular}{|c|c|c|}
\hline \multirow[b]{2}{*}{ BOSS Items } & \multicolumn{2}{|c|}{ Component (Factor) } \\
\hline & $\begin{array}{l}\text { Communication- } \\
\text { Aimed Bossing }\end{array}$ & $\begin{array}{l}\text { Psyche-Aimed } \\
\text { Bossing }\end{array}$ \\
\hline $\begin{array}{l}\text { I am not allowed by the supervisor to comment on my } \\
\text { criticism. }\end{array}$ & .589 & \\
\hline I am not called by the supervisor for the operational meetings. & .684 & \\
\hline $\begin{array}{l}\text { I am not provided with a turn to speak according to my } \\
\text { interest by my supervisor at meetings. }\end{array}$ & .699 & \\
\hline $\begin{array}{l}\text { I am not allowed by my supervisor to access important, } \\
\text { undistorted, and not belated information to fulfill my tasks. }\end{array}$ & .748 & \\
\hline $\begin{array}{l}\text { The supervisor ceased communication with me, or } \\
\text { communicates with me only at a minimum level. }\end{array}$ & .821 & \\
\hline $\begin{array}{l}\text { I am not called by my supervisor for informal meetings of the } \\
\text { working group. }\end{array}$ & .667 & \\
\hline $\begin{array}{l}\text { My supervisor runs unreasonable and unjustified relocations } \\
\text { of my job position against my will. }\end{array}$ & .598 & \\
\hline $\begin{array}{l}\text { My supervisor ends the conversation abruptly when I enter } \\
\text { the room. }\end{array}$ & .734 & \\
\hline $\begin{array}{l}\text { My supervisor (directly or indirectly) spreads defamation, } \\
\text { half-truths, gossip, intrigues, and unsubstantiated claims } \\
\text { about me. }\end{array}$ & .730 & \\
\hline $\begin{array}{l}\text { My opinions are ignored by my supervisor and my views are } \\
\text { casted doubt on. }\end{array}$ & .734 & \\
\hline $\begin{array}{l}\text { My supervisor criticizes me for my religious, political, and } \\
\text { other convictions. }\end{array}$ & & .551 \\
\hline
\end{tabular}


End of Table $1 a$

\begin{tabular}{|l|c|c|}
\hline \multirow{2}{*}{ BOSS Items } & \multicolumn{2}{c|}{ Component (Factor) } \\
\cline { 2 - 3 } & $\begin{array}{c}\text { Communication- } \\
\text { Aimed Bossing }\end{array}$ & $\begin{array}{c}\text { Psyche-Aimed } \\
\text { Bossing }\end{array}$ \\
\hline $\begin{array}{l}\text { My supervisor has invented an unflattering, derogatory } \\
\text { nickname for me. }\end{array}$ & & .524 \\
\hline My supervisor denies me any business education. & & .540 \\
\hline $\begin{array}{l}\text { My work and/or personal belongings and work results are } \\
\text { damaged by my supervisor. }\end{array}$ & & .651 \\
\hline I get threatened with physical violence by my supervisor. & & .773 \\
\hline $\begin{array}{l}\text { I am sexually harassed by my supervisor (repeated refused } \\
\text { invitations, jokes, touching, proposals, etc.). }\end{array}$ & & .864 \\
\hline My supervisor casts doubt on my mental state. & & .816 \\
\hline
\end{tabular}

Table 1b. Basic parameters of the BOSS factor structure

\begin{tabular}{|l|c|c|c|}
\hline \multicolumn{1}{|c|}{ Component } & Eigenvalue & \% of Variance & Cumulative \% \\
\hline Communication-Aimed Bossing & 7.010 & 41.236 & 41.236 \\
\hline Psyche-Aimed Bossing & 2.200 & 12.944 & 54.180 \\
\hline \multicolumn{4}{|c|}{ Rotation Sums of Squared Loadings } \\
\hline Component & Eigenvalue & $\%$ of Variance & Cumulative \% \\
\hline Communication-Aimed Bossing & 5.475 & 32.206 & 32.206 \\
\hline Psyche-Aimed Bossing & 3.736 & 21.974 & 54.180 \\
\hline
\end{tabular}

The extracted BOSS factors were labeled and specified as:

1. COMMUNICATION-AIMED BOSSING: Respondents, who score high in this factor, perceive the communication of their supervisor as unsatisfactory and minimal; they feel they are not allowed to comment on criticism and access undistorted information to carry out their tasks; they are not provided a turn to speak as they wish during business meetings; they are not invited for informal or operational meetings of the working group; the conversation ceases suddenly and abruptly upon their entering the room; and the supervisor casts doubt on their views and performs unjustified and senseless actions which are against their will, such as spreading defamation, half-truths, gossip, intrigues, and unsubstantiated claims.

2. PSYCHE-AIMED BOSSING: Respondents with high scores in this factor feel criticized by their supervisor for their religious, political, and other convictions; they perceive their supervisor as damaging their work results and belongings; they feel threatened with physical violence and sexually harassed by their supervisor, who also gives them defamatory, unflattering nicknames, denies them additional business education, and questions their mental state. 
The two factors extracted by the factor analysis explain $54.180 \%$ of the variance, which is an acceptable percentage as it enables content-specification of the extracted factors. The Cronbach's alpha coefficients were calculated to determine the internal consistency of the individual BOSS factors as their reliability indicator (Tables 2, 3).

Table 2. Communication-Aimed Bossing internal consistency

\begin{tabular}{|l|c|c|c|c|}
\hline & $\begin{array}{c}\text { Scale Mean if } \\
\text { Item Deleted }\end{array}$ & $\begin{array}{c}\text { Scale Variance } \\
\text { if Item } \\
\text { Deleted }\end{array}$ & $\begin{array}{c}\text { Corrected } \\
\text { Item-Total } \\
\text { Correlation }\end{array}$ & $\begin{array}{c}\text { Cronbach's } \\
\text { Alpha if Item } \\
\text { Deleted }\end{array}$ \\
\hline $\begin{array}{l}\text { I am not allowed by the supervisor } \\
\text { to comment on my criticism. }\end{array}$ & 13.58 & 34.435 & .502 & .900 \\
\hline $\begin{array}{l}\text { I am not called by the supervisor } \\
\text { for the operational meetings. }\end{array}$ & 13.88 & 33.919 & .600 & .892 \\
\hline $\begin{array}{l}\text { I am not provided with a turn to } \\
\text { speak according to my interest by } \\
\text { my supervisor at meetings. }\end{array}$ & 14.02 & 34.482 & .668 & .887 \\
\hline $\begin{array}{l}\text { I am not allowed by my supervisor } \\
\text { to access important, undistorted, } \\
\text { and not belated information to } \\
\text { fulfill my tasks. }\end{array}$ & 13.90 & 33.488 & .675 & .886 \\
\hline $\begin{array}{l}\text { The supervisor ceased } \\
\text { communication with me, or } \\
\text { communicates with me only at a } \\
\text { minimum level. }\end{array}$ & 13.91 & 32.298 & .797 & .878 \\
\hline $\begin{array}{l}\text { I am not called by my supervisor } \\
\text { for informal meetings of the } \\
\text { working group. }\end{array}$ & 13.96 & 34.275 & .574 & .893 \\
\hline $\begin{array}{l}\text { My supervisor runs unreasonable } \\
\text { and unjustified relocations of my } \\
\text { job position against my will. }\end{array}$ & 14.16 & 35.724 & .574 & .893 \\
\hline $\begin{array}{l}\text { My supervisor ends the } \\
\text { conversation abruptly when I enter } \\
\text { the room. }\end{array}$ & 14.00 & 33.842 & .722 & .895 \\
\hline $\begin{array}{l}\text { My supervisor (directly or } \\
\text { indirectly) spreads defamation, } \\
\text { half-truths, gossip, intrigues, and } \\
\text { unsubstantiated claims about me. }\end{array}$ & 13.96 & 33.893 & & .895 \\
\hline $\begin{array}{l}\text { My opinions are ignored by my } \\
\text { supervisor and my views are casted } \\
\text { doubt on. }\end{array}$ & 13.91 & 34.135 & & \\
\hline \multicolumn{1}{c|}{ Cronbach's Alpha } & & & & \\
\hline
\end{tabular}

The internal consistency of the items, which saturate the two specified factors, is within the range of acceptability, as proved by the calculated values of Cronbach's alpha coefficient. The inter-correlation coefficient values between the individual factors also support the proposed BOSS methodology structure (Table 4). 
Table 3. Psyche-Aimed Bossing internal consistency

\begin{tabular}{|c|c|c|c|c|}
\hline & $\begin{array}{l}\text { Scale Mean if } \\
\text { Item Deleted }\end{array}$ & $\begin{array}{c}\text { Scale Variance } \\
\text { if Item } \\
\text { Deleted }\end{array}$ & $\begin{array}{l}\text { Corrected } \\
\text { Item-Total } \\
\text { Correlation }\end{array}$ & $\begin{array}{l}\text { Cronbach's } \\
\text { Alpha if Item } \\
\text { Deleted }\end{array}$ \\
\hline $\begin{array}{l}\text { My supervisor criticizes me for } \\
\text { my religious, political, and other } \\
\text { convictions. }\end{array}$ & 6.76 & 3.435 & .542 & .796 \\
\hline $\begin{array}{l}\text { My supervisor has invented an } \\
\text { unflattering, derogatory nickname } \\
\text { for me. }\end{array}$ & 6.83 & 3.918 & .497 & .800 \\
\hline $\begin{array}{l}\text { My supervisor denies me any } \\
\text { business education. }\end{array}$ & 6.65 & 3.094 & .570 & .802 \\
\hline $\begin{array}{l}\text { My work and/or personal } \\
\text { belongings and work results are } \\
\text { damaged by my supervisor. }\end{array}$ & 6.78 & 3.455 & .641 & .774 \\
\hline $\begin{array}{l}\text { I get threatened with physical } \\
\text { violence by my supervisor. }\end{array}$ & 6.89 & 4.132 & .563 & .798 \\
\hline $\begin{array}{l}\text { I am sexually harassed by my } \\
\text { supervisor (repeated refused } \\
\text { invitations, jokes, touching, } \\
\text { proposals, etc.). }\end{array}$ & 6.89 & 3.936 & .652 & .784 \\
\hline $\begin{array}{l}\text { My supervisor casts doubt on my } \\
\text { mental state. }\end{array}$ & 6.86 & 3.811 & .644 & .781 \\
\hline Cronbach's Alpha & \multicolumn{4}{|c|}{$\mathrm{N}$ of Items } \\
\hline .815 & \multicolumn{4}{|c|}{7} \\
\hline
\end{tabular}

Table 4. Inter-correlation coefficient values of the BOSS methodology factors

\begin{tabular}{|l|l|c|}
\hline \multicolumn{2}{|c|}{} & Psyche-Aimed Bossing $^{|c|} .561^{* \star}$ \\
\hline \multirow{2}{*}{$\begin{array}{l}\text { Communication-Aimed } \\
\text { Bossing }\end{array}$} & Pearson Correlation & .000 \\
\cline { 2 - 3 } & Sig. (2-tailed) & 525 \\
\cline { 2 - 3 } & $\mathrm{N}$ & \\
\hline
\end{tabular}

The extracted BOSS factors representing the bossing indicators correlate with each other, i.e. they are mutually statistically significantly inter-related. In this sense, the respondents, whose supervisor does not give them a chance to express their own opinion at the meetings and allow them to comment on their criticism, are not provided with the important information and sufficient communication from the supervisor or manager, who also ignores their opinions, simultaneously perceive the mental assaults of their supervisor in the form of questioning their psychological condition, criticisms of their conviction, derogatory nicknames, and harassment.

From the viewpoint of validation of the BOSS methodology, the correlation coefficients between the extracted factors of this methodology were analyzed: Communication-Aimed Bossing, Psyche-Aimed Bossing and the overall NAQ methodology score (Table 5). The obtained results confirmed the existence of statistically significant correlation coefficients be- 
tween the two factors of the BOSS methodology and the overall NAQ methodology score. The higher the scores of the respondents in the NAQ methodology, the higher their scores in the BOSS methodology. This finding proves that the more negatively the respondents assessed the bullying phenomenon in general, the more negatively they also assessed the manifestations of bossing in terms of communication and psyche.

The presented statistically significant correlations indicate the suitability of analyzing, within the general level of bossing, also the individual factors that make up the internal structure of this construct. This idea is also supported by statistically significant differences in the extracted factors assessment (Table 5).

Table 5. Correlations of the BOSS and NAQ factors

\begin{tabular}{|l|l|c|c|}
\hline \multicolumn{2}{|c|}{} & Communication-Aimed Bossing & Psyche-Aimed Bossing \\
\hline \multirow{4}{*}{ NAQ } & Pearson Correlation & .512 & .466 \\
\cline { 2 - 4 } & Sig. (2-tailed) & .000 & .000 \\
\cline { 2 - 4 } & N & 525 & 525 \\
\hline
\end{tabular}

The extracted factors of the BOSS methodology: Communication-Aimed Bossing and Psyche-Aimed Bossing were assessed statistically significantly differently by the respondents. Employees assessed these factors in the sense of a more explicit rejection of the manifestations of mental bossing (Table 6).

Table 6. Assessment of the BOSS methodology factors

\begin{tabular}{|l|l|c|c|c|c|c|}
\hline \multicolumn{2}{|c|}{} & $\mathrm{M}$ & $\mathrm{N}$ & $\mathrm{SD}$ & $\mathrm{t}$ & $\mathrm{p}$ \\
\hline \multirow{2}{*}{ Pair 1 } & Communication-Aimed Bossing & 1.55 & 525 & .644 & \multirow{2}{*}{17.656} & \multirow{2}{*}{0.000} \\
\cline { 2 - 7 } & Psyche-Aimed Bossing & 1.13 & 525 & .315 & & \\
\hline
\end{tabular}

This means that the employees are less confronted with mental attacks by their superiors at work (sexual harassment, questioning of their psychological state, ridiculing, giving defamatory nicknames, denying further education, threatening, damaging the work results, etc.) than with various forms of communication constraint (ignoring their point of view, not providing information or space for expression, not allowing comments on criticism, not inviting them for business meetings, not providing them with a turn to speak, disallowing access to information, keeping communication at minimum, abrupt termination of conversation upon entering the room, spreading ill words about them, casting doubt on their views, etc.). Similar results have been reported from the research presented by Hoel, Cooper and Faragher (2001), Mikkelsen, and Einarsen (2001).

It should be noted that the two bossing manifestations were assessed by the employees to a varying extent on the disagreement part of the scale. This does not mean, however, that this issue does not need to be addressed. 


\section{Recommendations}

From the viewpoint of future research on the given issue, several steps could be taken. First of all, the cultural context should be considered as a possible limitation or another study direction, as bossing can manifest itself differently within various cultures. In this sense, also the concept of staffing, i.e. upward bullying could be analyzed and further compared within various settings. As this study suggests, the issue of bossing should be approached taking into account the hierarchy of an organization, as well. To what extent is bossing prominent on the different levels of management is yet another question provoking deeper discussion.

Several aforementioned studies have argued about bossing in connection to the performance of individuals in an organization, as well as the organization as a whole. Another recommendation would be to study this matter in greater detail as the findings may reveal a possible positive effect of a negatively perceived phenomenon - here it is crucial to distinguish between what is bossing or abusive supervision (performance decrease) and what is requiring consistent performance of duties (performance increase).

In terms of organizations as wholesome entities, introduction of several systems could be suggested, e.g. corporate culture or the system of quality management within which it is possible to design a system of abusive behavior manifestations control. From the viewpoint of implementation of the acquired results into practice, organizations could also use various forms of corporate training for further education of their employees.

At the same time, it is crucial to highlight the necessity to study the issue of abusive supervision or bossing in the context of the conditions of occurrence of this behavior on the one hand, and personality traits on the other. The presented concept of bossing may be regarded as a dispositional approach, which defines this issue as a personality trait, and on the basis of which behavior can be predicted trans-situationally in terms of the interaction between the supervisor and the subordinate.

The consequences of bossing for a particular company lie in the deterioration of the psychosocial environment, in increased staff turnover, in the lack of motivation and the increase in financial costs for maintaining work performance (Morovicsová, 2015). Since it has been found to occur, it is possible to find measures and to prevent it. In conclusion, it is essential to state that the limitations of this research are clear, and in the future studies, bossing as a negative social phenomenon can be observed and analyzed also in connection with other social phenomena, such as social and emotional intelligence (Birknerová et al., 2015, 2010).

\section{Conclusions}

The manifestations of bossing are an important factor in predicting and interpreting the behavior of people in different social contexts of work. One of the common denominators of these manifestations is the reduction of labor productivity, the increase of tension and absenteeism.

From the point of view of operationalization but also conceptualization of the issue of bossing, a significant attribute is represented by the existence of appropriate methodologies that detect the above manifestations in the workplace. 
The presented concept and methodology of detecting bossing manifestations represent a dispositional approach to the detection of this feature. This means that the trans-situational action of these characteristics in the behavior of employees in different social contexts of work is anticipated. It should be noted that this approach is one of the possible concepts, and that it is productive to consider a possible situational approach in the sense of a more general discussion about the situational or the dispositional concept of identifying the predictors of behavior.

The extracted, content-specified BOSS factors, i.e. Communication-Aimed Bossing and Psyche-Aimed Bossing are representatives of two crucial areas within which the bossing manifestations can be observed. Regarding these manifestations, it should be pointed out that their practical implementation may be disguised in various manners.

From the point of view of communication-aimed bossing, it is necessary, for example, to immediately solve the problems and the incompetence of the employee. In terms of psycheaimed bossing, it is, for instance, the absence of other people, thus ultimately the resolution of complaints about these manifestations, which is based only on a claim against the claim. Masking is also manifested by the prevalence of occurrence of manipulative behavior over the occurrence of direct aggression.

The definition of the two-factor bossing structure in the context of the presented BOSS methodology points, at the same time, to the structural approach to this issue. This is also confirmed by a statistically significant difference in the assessment of these bossing manifestations by employees.

The presented study is substantial as it supports the use of the measurement approach to bossing that is beneficial in terms of practical needs, which is shown by the verification data on the concept of the BOSS methodology obtained so far. The limitations of the acquired findings are obvious - the presented concept and methodology need to be verified in more universal contexts, notably the cultural one.

\section{Acknowledgements}

The contribution was compiled as part of the KEGA projects No. 003PU-4/2017 (Coping with demanding situations - subject innovation and university textbook preparation) and No. 012PU-4/2020 (Trading Behavior - Creation of the subject and textbook for non-economic study programs).

\section{Author contributions}

Zuzana Birknerová conceived the study and was responsible for the design, development of the data analysis, and data interpretation. Milan Droppa was responsible for data collection and analysis. Lucia Zbihlejová was responsible for data interpretation and also wrote the first draft of the article. The paper is published in memory of Miroslav Frankovský, who passed away in the course of its publication. 


\section{Disclosure statement}

All the authors hereby declare that they do not have any competing financial, professional, or personal interests from other parties.

\section{References}

Antonyová, A., Antony, P., Soewito, B., Abdullah, A. H. B., \& Nagapan, S. (2018). Reflection of gross domestic product into the income values according to the attained level of education in Europe. Advanced Science Letters, 24(12), 9261-9265. https://doi.org/10.1166/asl.2018.12250

Arnejčič, B. (2016). Mobbing in company: Levels and typology. Organizacija, 49(4), 240-250. https://doi.org/10.1515/orga-2016-0021

Bednař, Z. (2016). Jak vyjít se svým šéfem [How to get along with your boss]. Grada Publishing.

Bellizzi, J. A. (2006). Disciplining top-performing unethicalsalespersons: Examining the moderating effects of ethicalseriousness and consequences. Psychology \& Marketing, 23, 181-201. https://doi.org/10.1002/mar.20106

Bennett, R. J. (2000). Development of a measure of workplace deviance. Journal of Applied Psychology, 85(3), 349-360. https://doi.org/10.1037/0021-9010.85.3.349

Beňo, P. (2003). Mưj šéf, můj neprritel [My boss, my enemy]. Era.

Birknerová, Z., \& Frankovský, M. (2017). Nežiaduce formy správania manažérov [Undesirable forms of managerial behavior]. Bookman, Ltd.

Birknerová, Z., Frankovský, M., \& Zbihlejová, L. (2015). Emotional and social intelligence. In L. Zysberg \& S. Raz (Eds.), Emotional intelligence: Current evidence from psychophysiological, educational and organizational perspectives (pp. 239-254). Nova Science Publishers.

Birknerová, Z., Juhás, J., \& Litavcová, E. (2010). Connection between social intelligence, fear and mobbing in school environment. In Sociální procesy a osobnost 2009 (pp. 22-30). PsÚ AV ČR, v.v.i.

Borská, I. (2005). Mobbing a bossing - jak se bránit? [Mobbing and bossing - how to defend yourself]. Personální a sociálně právní kartotéka, 11, 8-10.

Brees, J., Martinko, M., \& Harvey, P. (2016). Abusive supervision: Subordinate personality or supervisor behavior? Journal of Managerial Psychology, 31(2), 405-419. https://doi.org/10.1108/JMP-04-2014-0129

Camps, J., Stouten, J., \& Euwema, M. (2016). The relation between supervisors' Big Five personality traits and employees' experiences of abusive supervision. Frontiers in Psychology,7, 112.

https://doi.org/10.3389/fpsyg.2016.00112

Davenport, N., Schwartz, R. D., \& Elliott, G. P. (1999). Mobbing - emotional abuse in the American workplace. AMES, Civil Society Publishing.

Directive (EU) 2016/680. (2016). Directive (EU) 2016/680 of the European Parliament and of the Council of 27 April 2016 on the protection of natural persons with regard to the processing of personal data by competent authorities for the purposes of the prevention, investigation, detection or prosecution of criminal offences or the execution of criminal penalties, and on the free movement of such data, and repealing Council Framework Decision 2008/977/JHA. https://eur-lex.europa.eu/legal-content/EN/ TXT/?uri=CELEX\%3A32016L0680

Droppa, M., Chocholáková, A., Čarnogurský, K., \& Sirotiaková, M. (2018). Assessment of bossing in secondary school environment of the Slovak Republic in category social relations area and area of working life. Human Resources Management \& Ergonomics, 12(1), 59-69. 
Einarsen, S., Hoel, H., \& Notelaers, G. (2009). Measuring exposure to bullying and harassment at work: Validity, factor structure and psychometric properties of the Negative Acts Questionnaire - Revised. Work \& Stress, 23(1), 24-44. https://doi.org/10.1080/02678370902815673

Einarsen, S., Raknes, B. I., Matthiesen, S. B., \& Hellesøy, O. H. (1994). Mobbing og harde personkonflikter: Helsefarlig samspill på arbeidsplassen [Bullying and personified conflicts: Health-endangering interaction at work]. Sigma Forlag.

Einarsen, S., Hoel, H., Zapf, D., \& Cooper, C. L. (2011). The concept of bullying and harassment at work: The European tradition. In S. Einarsen, H. Hoel, D. Zapf, \& C. L. Cooper (Eds.), Bullying and harassment in the workplace: Developments in theory, research, and practice (2 ${ }^{\text {nd }}$ ed., pp. 3-39). Taylor \& Francis Group. https://doi.org/10.1201/EBK1439804896-3

Emelander, S. (2011). Managing, leading, and bossing. Defense AT\&L, July-August 2011, 76-78.

Frankovský, M., Birknerová, Z., \& Droppa, M. (2019a). Methodological study of the selected attributes of the bossing questionnaire. Journal of Management and Business: Research and Practice, 11(1), $28-36$.

Frankovský, M., Birknerová, Z., \& Droppa, M. (2019b). Assessment of bossing and mobbing manifestations in the context of personality traits of employees. Proceedings from 18th International Conference on Work and Organizational Psychology 2019. Masaryk University, Brno (in press). https://doi.org/10.5817/CZ.MUNI.P210-9488-2019-10

Hafidz, S. M. (2012). Individual differences as antecedents of counterproductive work behaviour. Social Science, 8(3), 220-226. https://doi.org/10.5539/ass.v8n13p220

Hamilton, D. I., Ogbuigwe, T., \& Gabriel, J. M. O. (2017). Narcissistic bossing and deviant workplace behavior among subordinates in the Nigerian civil service. International Journal of Arts and Humanities, 1(9), 735-762.

Hirigoyen, M. F. (2000). Stalking the soul: Emotional abuse and the erosion of identity. Helen Marx Books.

Hoel, H., Rayner, C., \& Cooper, C. (1999). Workplace bullying. International Review of Industrial and Organizational Psychology, 14, 195-230.

Hoel, H., Cooper, C., \& Faragher, B. (2001). The experience of bullying in Great Britain: The impact of organizational status. European Journal of Work and Organizational Psychology, 10(4), 443-465. https://doi.org/10.1080/13594320143000780

Howladar, M. H. R., Rahman, S., \& Uddin, A. (2018). Deviant workplace behavior and job performance: The moderating effect of transformational leadership. Iranian Journal of Management Studies, 11(1), 147-183.

Huberová, B. (1995). Psychický teror na pracovisku [Mental terror in the workplace]. Neografia.

Jenčo, M., Droppa, M., Lysá, L., \& Križo, P. (2018). Assessing the quality of employees in terms of their resistance. QUALITY-Access to Success, 19(167), 48-53.

Karabacak Aşır, S., \& Akın, G. (2014). İlköğretim okullarındaki yıldırmaya (mobbing) toplumsal cinsiyet bağlamında bir bakış. Mobbing in primary schools in the context of gender perspective. International Journal of Human Sciences, 11(1), 584-602. https://doi.org/10.14687/ijhs.v11i1.2655

Kariková, S., \& Šimegová, M. (2005). Bullying, mobbing and bossing as the types of violence in schools. The New Educational Review, 7, 79-95.

Kolář, M. (2005). Bolest šikanování [The pain of bullying]. Portál.

Kratz, H. J. (2005). Mobbing (1 $1^{\text {st }}$ ed.). Management press.

Leymann, H. (1990). Mobbing and psychological terrors at work. Violence and Victims, 5(2), 119-126. https://doi.org/10.1891/0886-6708.5.2.119

Leymann, H. (1996). The content and development of mobbing at work. European Journal of Work and Organizational Psychology, 5(2), 165-184. https://doi.org/10.1080/13594329608414853 
Lu, L. (2013). Abusive supervision and its organizational performance: a grounded study on the biography of Steve Jobs. Journal of Manangement Case Studies, 5, 20-31.

Mikkelsen, E., \& Einarsen, S. (2001). Bullying in Danish work-life: Prevalence and health correlates. European Journal of Work and Organizational Psychology, 10(4), 393-413. https://doi.org/10.1080/13594320143000816

Mikušová, M., \& Horváthová, P. (2012). Are you prepared for a crisis? Survey in Czech small enterprises. Actual Problems of Economics, 137(11), 403-411.

Morovicsová, E. (2015). Mobbing - jeho vplyv na zdravie a možnosti prevencie [Mobbing - its impact on health and prevention possibilities]. Psychiatria pre prax, 16(3), 111-114.

Nekoranec, J., \& Kmošena, M. (2015). Mobbing in the workplace - its manifestations, consequences and possibilities of elimination in the Armed Forces of the Slovak Republic. Revista Academiei Fortelor Terestre, 20(1), 47-54.

Novák, T. (2004). Jak bojovat se stresem [How to fight stress]. Grada Publishing.

Novák, T., \& Capponi, V. (1996). Sám proti agresi [Alone against agression]. Grada Publishing.

Oberhofer, P. (2018). Bossing und staffing: Mobbing zwischen Chef und Mitarbeitern. Konfliktmanagement. https://www.jobadu.de/pdfs/01502.pdf

Olšovská, A. (2013). Mobbing a bossing na pracovisku [Mobbing and bossing in the workplace]. Správa z VÚ č. 2162. Institute for Labour and Family Research.

Regulation (EU) 2016/679. (2016). Regulation (EU) 2016/679 of the European Parliament and of the Council of 27 April 2016 on the protection of natural persons with regard to the processing of personal data and on the free movement of such data, and repealing Directive 95/46/EC (General Data Protection Regulation) (Text with EEA relevance). https://eur-lex.europa.eu/eli/reg/2016/679/oj

Russo, A., \& Popović, T. (2016). Workplace agression: Secondary analysis of Croatian research practice [Agresivnost na radnom mjestu: Sekundarna analiza istraživačke prakse u Hrvatskoj]. Sigurnost: časopis za sigurnost u radnoj i životnoj okolini, 58(2), 121-135. https://doi.org/10.31306/s.58.2.1

Safina, D., \& Podgornaya, A. (2014). Mobbing as an organizational phenomenon impeding implementation of changes. Mediterranean Journal of Social Sciences, 5(18), 187-192. https://doi.org/10.5901/mjss.2014.v5n18p187

Senol, V., Avsar, E., Peksen Akca, R., Argun, M., Avsarogullari, L., \& Kelestimur, F. (2015). Assessment of mobbing behaviors exposed by the academic personnel working in a university, in Turkey. Journal of Psychiatry, 18(1), 212. https://doi.org/10.4172/Psychiatry.1000212

Smith, P. K., Thompson, F., Craig, W., Hong, I., Slee, P., Sullivan, K., \& Green, V. A. (2016). Actions to prevent bullying in western countries. In P. K. Smith, K. Kwak, \& Y. Toda (Eds.), School bullying in different cultures: Eastern and western perspectives (pp. 301-333). Cambridge University Press. https://doi.org/10.1017/CBO9781139410878.018

Štefko, R., Bačík, R., Fedorko, R., Gavurová, B., Horváth, J., \& Propper, M. (2017). Gender differences in the case of work satisfaction and motivation. Polish Journal of Management Studies, 16(1), 215-225. https://doi.org/10.17512/pjms.2017.16.1.18

Svobodová, L. (2007). Bezpečný podnik: Mobbing - nebezpečný fenomén naší doby [A safe company: Mobbing - a dangerous phenomenon of our era]. Výzkumný ústav bezpečnosti práce.

Tepper, B. J. (2000). Consequences of Abusive supervision. The Academy of Management Journal, 43(2), 178-190. https://doi.org/10.2307/1556375

Tomková, A., \& Lorincová, T. (2017). Prediction of manipulation as a core part of social intelligence through selected personality traits in the context of business area. International Journal of Organizational Leadership, 6(1), 102-108. https://doi.org/10.33844/ijol.2017.60227

Tuzunkan, D. (2018). Mobbing in tourism enterprises: The case of Turkish Riviera. International Journal of Applied Engineering Research, 13(4), 1813-1819. 
Wilson, C. J., \& Nagy, M. S. (2017). The effects of personality on workplace bullying. The PsychologistManager Journal, 20(3), 123-147. https://doi.org/10.1037/mgr0000054

Wu, W.-J., Chen, C.-Y., \& Chien, Y.-Y. (2018, October). Predictors of abusive supervision: Organizational identification and the role of individual difference. In ICIBE' 18: Proceedings of the 4th International Conference on Industrial and Business Engineering (pp. 109-114). Macau, Macao. https://doi.org/10.1145/3288155.3288177

Yaman, E. (2009). The validity and reliability of the mobbing scale (MS). Educational Sciences: Theory \& Practice, 9(2), 981-988.

Ylldiz, S. M. (2015). The relationship between bullying and burnout: An empirical investigation of Turkish professional football players. Sport, Business and Management: An International Journal, 5(1), 6-20. https://doi.org/10.1108/SBM-09-2012-0034

Zacharová, E., \& Bartošovič, I. (2016). Mobbing experienced by nurses in health care facilities. Clinical Social Work and Health Intervention, 7(2), 50-61. https://doi.org/10.22359/cswhi_7_2_07

Zapf, D., \& Leymann, H. (1996). Mobbing and victimization at work. A Special Issue of the European Journal of Work and Organizational Psychology. Psychology Press.

Zhao, T. (2018). The effect of abusive supervision on job performance: The role of leadership identification and subordinates' tradition. Research in Economics and Management, 3(2), 149-155. https://doi.org/10.22158/rem.v3n2p149

Zikic, S., Paunkovic, J., \& Cvetkovic, A. (2013). The organizational structure affects the occurrence of mobbing. Proceedings: Advances in Fiscal, Political and Law Science, The 2nd International Conference on Economics, Political and Law Science (EPLS '13) (pp. 232-236). Brasov, Romania.

Zukauskas, P., \& Vveinhardt, J. (2011). Mobbing diagnosis instrument: stages of construction, structure and connectedness of criteria. Journal of Business Economics and Management, 12(2), 400-416. https://doi.org/10.3846/16111699.2011.575193

Zukauskas, P., Vveinhardt, J., Melnikas, B., \& Grančay, M. (2015). Dynamics of attack actions in the mobbing strategy: The case of Lithuania. Journal of Business Economics and Management, 16(4), 733-752. https://doi.org/10.3846/16111699.2015.1068840 